\title{
Control of Leaf Spot Diseases on Ecotypes of Faba Bean (Vicia faba L.) Produced in the Andean Region of Bolivia
}

\author{
M. Coca-Morante ${ }^{1}$, F. Mamani-Álvarez ${ }^{2}$ \\ ${ }^{1}$ Departamento de Fitotecnia y Producción Vegetal, Facultad de Ciencias Agrícolas, Pecuarias, Forestales y Veterinarias Dr. "Martín \\ Cárdenas", Universidad Mayor de San Simón (UMSS), Cochabamba, Bolivia; ${ }^{2}$ Instituto Nacional de Investigación Agrícola y \\ Forestal (INIAF), La Paz, Bolivia. \\ Email: cocamorante.mario@gmail.com
}

Received May $12^{\text {th }}, 2012$; revised June $7^{\text {th }}, 2012$; accepted June $17^{\text {th }}, 2012$

\begin{abstract}
The basin of Lake Titicaca is a faba bean-producing microregion of Bolivia where the crop is destined for export. The most commonly cultivated ecotypes "Gigante de Copacabana" and "Usnayo" are affected by diseases that can cause production losses. The aims of the present work were to identify the causal agents of leaf spot affecting these ecotypes, to record disease intensity levels, and to estimate their effect on production. In 2004 and 2005, leaflet, stem and pod samples were taken from faba bean plants with leaf spot growing in the Lake Titicaca area, and from plants in an experimental plot established to determine the effect of five different treatments on production and disease intensity: $\mathrm{T}_{1}=$ Control; $\mathrm{T}_{2}=$ seed treatment with Trichoderma sp. + alternate foliar spraying with benomyl and mancozeb; $\mathrm{T}_{3}=$ seed treatment with fludioxanil/metalaxyl $\mathrm{M}+$ alternate foliar spraying with benomyl and mancozeb; $\mathrm{T}_{4}=$ foliar spraying with Trichoderma sp.; $\mathrm{T}_{5}=$ alternate foliar spraying with cymoxanyl and mancozeb-chlorothalonil. Microscopic analysis of the samples revealed the presence of new fungal pathogens for faba beans in Bolivia (Cladosporium sp., and Lepthosphaerulina sp.) as well as emerging fungal pathogens (Botrytis cinerea, B. fabae, Ascochyta fabae, Alternaria sp. and Cercospora sp.). None of the treatments affected the disease progression curve (DPC) for incidence, although effects were seen with respect to disease severity. The seed + foliar treatments $\left(T_{2}\right.$ and $\left.T_{3}\right)$ were more effective at controlling disease than leaf treatments on their own $\left(\mathrm{T}_{4}\right.$ and $\left.\mathrm{T}_{5}\right)$. Modelling analysis showed faba bean leaf spot disease to be moderately destructive. Compared to chemical treatments, biocontrol with Trichoderma spp. preliminary was found to provide good control of the disease. Losses due to leaf spot disease of $36 \%$ were recorded, and a strong correlation detected between yield and disease severity.
\end{abstract}

Keywords: Ecotypes; Modeling; Diseases Intensity

\section{Introduction}

In Bolivia, the faba bean (Vicia faba L.) is cultivated in the Andean highlands $(>3500 \mathrm{~m})$ and in a few valley microregions $(2000 \mathrm{~m})$ (Piérola, 1997). One of these lies in the basin of Lake Titicaca ( $3820 \mathrm{~m})$ on the Altiplano of La Paz. The crop is marketed as dry faba beans in Europe and Japan, although some is retained for the home market. The most cultivated ecotypes are "Gigante de Copacabana" and "Usnayo"; these show good productivity and produce large beans suitable for export [1,2].

Leaf diseases limit the production of faba beans. Otazu et al. [3] reported that in Bolivia those that most affect this crop are caused by the fungi Alternaria sp., Botrytis cinerea, B. fabae, Mycosphaerella sp., Oidium sp. and Uromyces viciae-fabae. De Quiton [4] later reported other diseases such as black spot to be caused by Alternaria alternata, and bacteriosis to be caused by Xantho- monas campestris. This author also reported the rust caused by $U$. viciae-fabae to be more destructive in valley areas, while B. fabae was more destructive at higher altitudes. It is thought that chocolate leaf spot (caused by B. cinerea and B. fabae) may occasion production losses of between 20 and $80 \%$ in Bolivia $[2,4]$. In recent years it has been noticed that leaf spot-understood as a complex of diseases - on faba bean has become more intense in this country Even diseases that are uncommon in the agrosystems of the Altiplano have been seen more often [5].

Damsteegt [6] defines new pathogens as those that have been detected within the last five years, while emerging pathogens are those that have become more common over the last 20 years. The control of diseases in faba bean mainly relies on chemical treatments. However, a number of authors indicate that the effect of leaf pathogens can be reduced by biological control with Tricho- 
derma [7-10]. Certainly, the suppression of plant pathogens can be achieved by a range of control methods that differ in their effectiveness, duration and cost [11], but to achieve the rational management of disease a number of factors need to be taken into account, such as the variation of prevalence (from year to year and from place to place) and disease intensity. It is essential to be able to estimate the intensity of disease if modelling is to help us understand the epidemiological process and the practices that might be successful in disease control [11,12]. The objectives of the present work were 1) Identify the causal agents of leaf spot in faba bean on the Altiplano of La Paz, Bolivia; 2) Record the intensity disease of leaf spot in the study area, and 3) Estimate the yield losses caused by the different pathogens involved.

\section{Materials and Methods}

\subsection{Study Area}

The present work was performed between August 2004 and June 2005 at three sites in the area of influence of Lake Titicaca (Department of La Paz) on the road between La Paz and Copacabana: Chirapaca (on the Altiplano Norte, $60 \mathrm{~km}$ from La Paz), Tiquina (95 km from
La Paz) and Chani (near Copacabana, $120 \mathrm{~km}$ from La Paz). The last two sites are on the shore of Lake Titicaca (Figure 1). The predominant climate in the area is cold and damp. The mean annual temperature is $10^{\circ} \mathrm{C}$; mean annual rainfall is $490-550 \mathrm{~mm}$ [13].

\subsection{Pathogen Identification}

Leaflet, stem and pod samples were taken from Gigante de Copacabana and Usnayo plants showing symptoms of leaf spot. These plants were growing either in agricultural plots in which the crop was destined for export, or in the experimental plot described below. All samples were taken from 30 - 45 days after emergence (October 2004) until pod ripening (April 2005). The pathogens affecting these plants were isolated on potato dextrose agar (PDA) and faba bean dextrose agar (FBDA). Preparations mounted in lactophenol were prepared on microscope slides for observation with an Olympus $\mathrm{CH} 30$ RF200 microscope. The causal agents of disease in each case were identified using the taxonomic keys of Chupp [14], Booth and Pirozynski [15], Ellis [16], Sutton [17] and Hanlin [18], and then categorised as new or emerging according to Damsteegt [6].

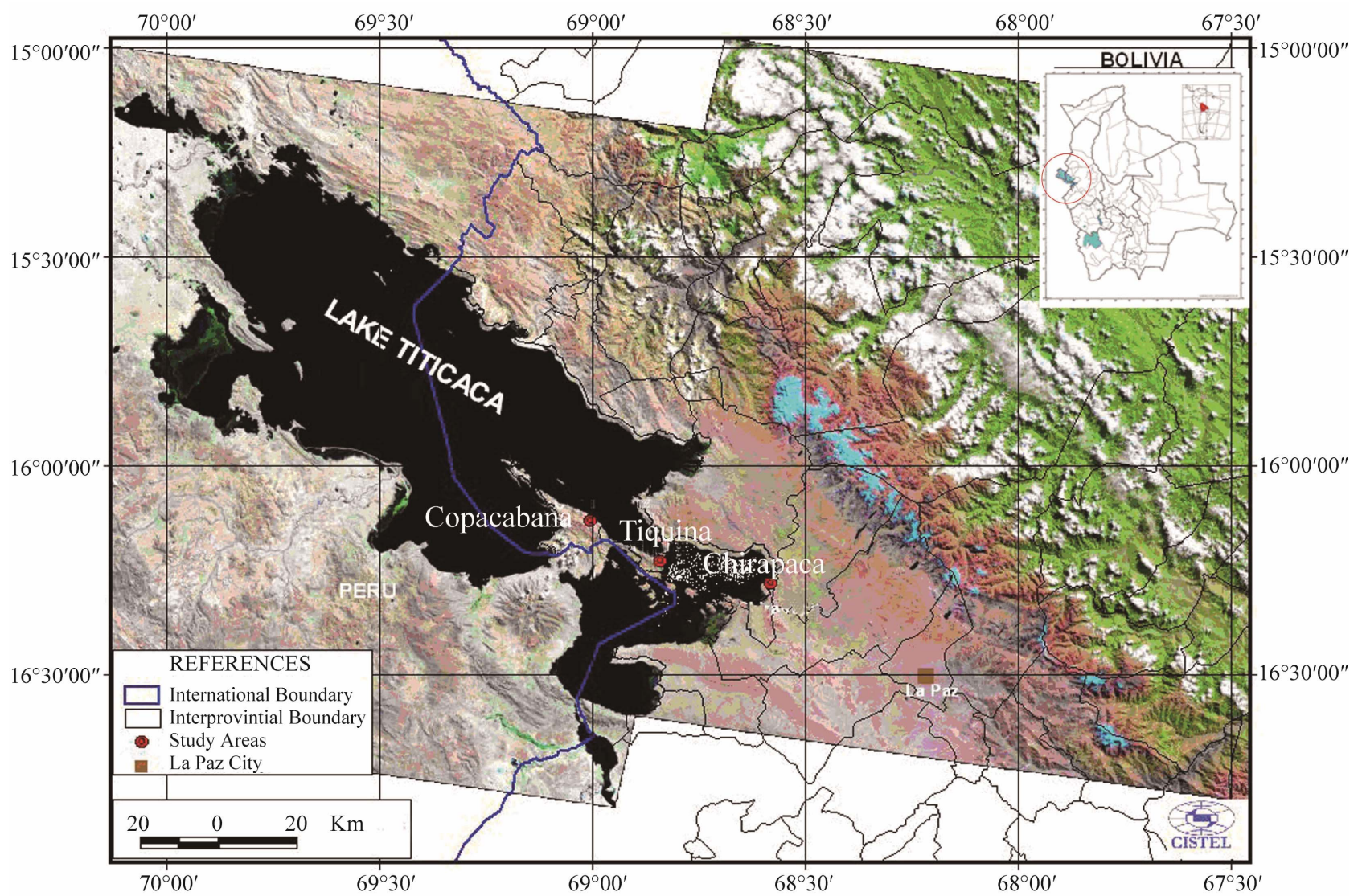

Figure 1. Sites of the three main micro regions producing the faba bean ecotypes Gigante de Copacabana and Usnayo on the Altiplano Norte de La Paz, Bolivia. 


\subsection{Incidence, and Severity Disease and Effect on Yield}

An experimental plot was established at Chirapaca locality, planting Usnayo seeds provided by the Instituto Boliviano de Tecnología Agropecuaria (IBTA). Sowing was performed on the 31st August 2004. The experimental design followed was that of random blocks with five treatments $\left(\mathrm{T}_{1}, \mathrm{~T}_{2}, \mathrm{~T}_{3}, \mathrm{~T}_{4}\right.$ and $\left.\mathrm{T}_{5}\right)$ and four replicates (Table 1). Each experimental unit (EU) had 6 rows $10 \mathrm{~m}$ long, with $0.8 \mathrm{~m}$ between rows and $0.3 \mathrm{~m}$ between sowing holes (two seeds per hole). The treatments consisted of combinations of different seed and foliar applications: $\mathrm{T}_{1}=$ foliar sprayed with $\mathrm{H}_{2} \mathrm{O}$ (every application); $\mathrm{T}_{2}=$ seeds immersed in Trichoderma sp. (using the contents of full Petri dish) and foliar sprayed alternately with a systemic (benomyl) (Commercial name Benlate) and protectant fungicide (mancozeb); $\mathrm{T}_{3}=$ seeds immersed in fludioxanil-metalaxyl (Commercial name Maxim XL) and foliar sprayed alternately with a systemic (benomyl) and protectant fungicide (mancozeb); $\mathrm{T}_{4}=$ foliar sprayed with Trichoderma sp (one full Petri dish every application); and $\mathrm{T}_{5}=$ foliar sprayed alternately with a systemic (cymoxanil-mancozeb) (Commercial name Curathane) and protectant fungicide (chlorothalonil) (Commercial name Bravo 500). All leaf treatments were applied 69 days after sowing and then every 14 days until the start of pod ripening. Chemical treatments were applied at commercial doses (Table 1). The fungus Trichoderma sp., isolated from leaves of Podocarpus plants [19], and was used as an observation treatment.

Disease incidence and severity was determined every 14 days on the plants in the two central rows, one day before the application of treatments. Incidence was determined as the number of plants with leaf spot disease symptoms divided by the total number of plants. Disease severity data were collected by marking and assessing 3 plants/row (i.e., 6 plants per EU); a branch on each plant was then marked and three representative leaflets sampled (lower, middle and upper). All sampled leaflets were dried and pressed. Disease severity was calculated as the percentage area affected by disease with respect to the total leaflet area [20] using Sigma Scan Pro V.5 software for Windows 95/98. The stems and pods were used for the identification of pathogens. The total dry grain yield $\left(\mathrm{Mg} \cdot \mathrm{ha}^{-1}\right)$ was determined for the two central rows (33 plants per row) selected for determining incidence and severity.

\subsection{Statistical Analyses}

Incidence and severity data were analysed using linearized forms of the monomolecular, logistic, Gompertz and exponential models using the PROC GLM utility supplied with the Statistical Analysis System (SAS) v.11 software package (Campbell and Madden, 1990). The apparent infection rate $(\mathrm{r})$ was estimated using with the adjustment formula $\operatorname{Ln}[\mathrm{y} /(1-\mathrm{y})][21]$, where $\mathrm{y}=$ disease intensity (incidence or severity).

\section{Results}

\subsection{New Fungal Pathogens Detected on Faba Bean}

\subsubsection{Cladosporium Leaf Spot (Cladosporium Link ex} Fr.)

This was present from emergence as isolated leaf spots. The same plants were often also infected with Ulocladium sp. and Alternaria tenuis. The symptoms of this disease, the type of colonies formed and the morphological and morphometric characteristics of the conidiophores and conidia were the same as those described for the genus Cladosporium sp. by Ellis (1971). Differences were seen among isolates in terms of their reproductive structures and growth in cultivation media, suggesting unidentified Cladosporium species were present (Figure 2(a)).

\subsubsection{Lepthosphaerulina Common Leaf Spot (Lepthosphaerulina sp.)}

In Chirapaca locality, symptoms typical of common leaf spot were seen on plants in the grain filling stage. The

Table 1. Treatments, active ingredients and application doses.

\begin{tabular}{|c|c|}
\hline Treatment & Active ingredient (dose in 20 l water) \\
\hline $\mathrm{T}_{1}$-Control & $\mathrm{H}_{2} \mathrm{O}$ \\
\hline $\mathrm{T}_{2}$-Seed immersion + leaf spraying & Trichoderma sp. $(1 \text { Petri dish })^{(2)}+40 \mathrm{~g}_{\text {benomyl }}{ }^{(1)} / 80 \mathrm{~g}_{\text {mancozeb }}{ }^{(3)}$ \\
\hline $\mathrm{T}_{3}$-Seed immersion + leaf spraying & $20 \mathrm{ml}$ fludioxanil/metalaxyl $\mathrm{l}^{(4)}+40 \mathrm{~g}$ benomyl $/ 80 \mathrm{~g}$ mancozeb $^{(3)}$ \\
\hline $\mathrm{T}_{4}$-Foliar spraying & Trichoderma sp. (1 Petri dish) ${ }^{(2)}$ \\
\hline $\mathrm{T}_{5}$-Foliar spraying & 70 g cymoxanil-mancozeb $^{(5)} / 60 \mathrm{ml}$ chlorothalonil ${ }^{(3,6)}$ \\
\hline
\end{tabular}

${ }^{(1)}$ Commercial name Benlate; ${ }^{(2)}$ One culture plate of Trichoderma sp. growing and actively sporulating on PDA medium; ${ }^{(3)}$ Alternate foliar spraying; ${ }^{(4)}$ Commercial name $=$ Maxim XL; ${ }^{(5)}$ Commercial name $=$ Curathane; ${ }^{(6)}$ :Commercial name $=$ Bravo 500 . $\mathrm{T}_{1}$ : foliar treatment with $\mathrm{H}_{2} \mathrm{O}$ only $($ every application); $\mathrm{T}_{2}$ : Seed immersion treatment with Trichoderma sp. (using the contents of one full Petri dish) and alternate foliar application of systemic (40 g benomyl) and protectant fungicides ( $80 \mathrm{~g}$ mancozeb); $\mathrm{T}_{3}$ : Seed immersion treatment with fludioxanil/metalaxyl and alternate foliar application of systemic (40 $\mathrm{g}$ benomyl) and protectant fungicides ( $80 \mathrm{~g}$ mancozeb); $\mathrm{T}_{4}$ : Foliar treatment with Trichoderma sp. only (one full Petri dish every application); $\mathrm{T}_{5}$ : Alternate foliar application of systemic (70 $\mathrm{g}$ de Curathane) and protectant fungicides (60 $\mathrm{ml}$ chlorothalonil). 
symptoms recorded and the morphological and morphotmetric characteristics of the pseudothecia, asci and ascospores were those described for Lepthosphaerulina trifolii by Booth and Pirozynski (1967) and Hanlin (1990) (Figure 2(b)). This type of leaf spot appears to be associated with the milder temperatures of February and March.

\subsection{Emerging Fungal Pathogens Detected on Faba Bean}

\subsubsection{Chocolate Leaf Spot (Botrytis fabae Sardiña and} B. cinerea Pers. ex Pers.)

In Chirapaca locality, chocolate leaf spot was non-aggressive during pre-flowering and post-flowering, and aggressive during flowering (110 days after sowing) and grain filling (166 days after sowing) (Figure 3). The isolates from Chirapaca appeared grey-white when cultivated in PDA and FBDA, and showed an abundant production of black sclerocia of variable size. In contrast, the isolates from Copacabana and Tiquina appeared white when grown on PDA and FB, but again produced abundant scleroci. The morphological and morphotmetric characteristics of the conidiophores and conidia were the same as those described by Ellis (1971) for B. fabae (isolates from Chirapaca) and B. cinerea (isolates from Copacabana and Tiquina) (Figure 2(e)).

\subsubsection{Ascochyta blight (Ascochyta fabae Speg.)}

Ascochyta blight was observed at three sites from grain filling to ripening (Figure 3). Symptoms included generalised leaf necrosis. In the beginning the disease was noticeable because of the irregular dark spots that form on the pods; when these spots mature they become dark brown and damp and picnidia appear (these symptoms are observed during grain drying before threshing the kalchas $^{1}$ ). The pycnidial were prominent, dark brown in colour, and distributed irregularly over the lesions. When moisture levels were high, clumps of conidial masses formed. Isolates grown on PDA were ash white in colour, but on FBDA appeared coffee-coloured with white borders and showed pycnidial when aged. The pycnidial were ostiolate and the conidia straight to slightly curved, mostly with one septum though sometimes with two or three septa, and measured $(15-22) \times(4.1-5.5) \mu$. The symptoms, the morphology of the reproductive organs, and the growth of the isolates in cultivation media were the same as those described for A. fabae Speg. by Punithalingam and Holliday (1969) and Sutton (1980).

\subsubsection{Alternaria and Cercospora Leaf Spots (Alternaria sp. and Cercospora sp.)}

Alternaria sp. and Cercospora sp. were found at three

${ }^{1} \mathrm{~A}$ word of Aymarian native language meaning "piles of cut plants undergoing drying before threshing.

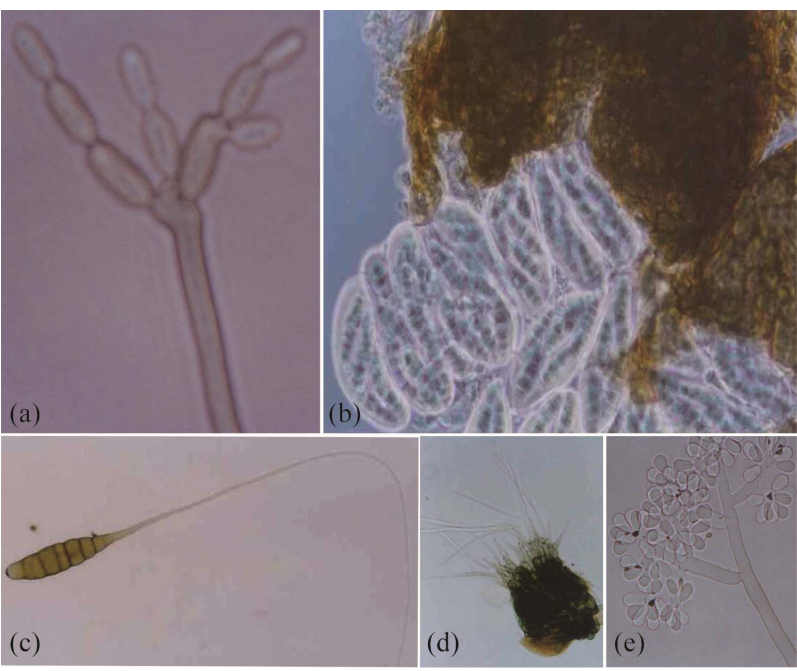

Figure 2. New and emerging pathogen structures. (a): Cladosporium sp. conidiophores and conidia; (b): Lepthosphaerulina sp. Asci, ascospores and Pseudothecium; (c): Alternaria sp. conidia; (d): Cercospora sp. conidiophore fasciculate and hyaline conidia; (e): Botrytis cinerea conidiophore and hyaline conidia.

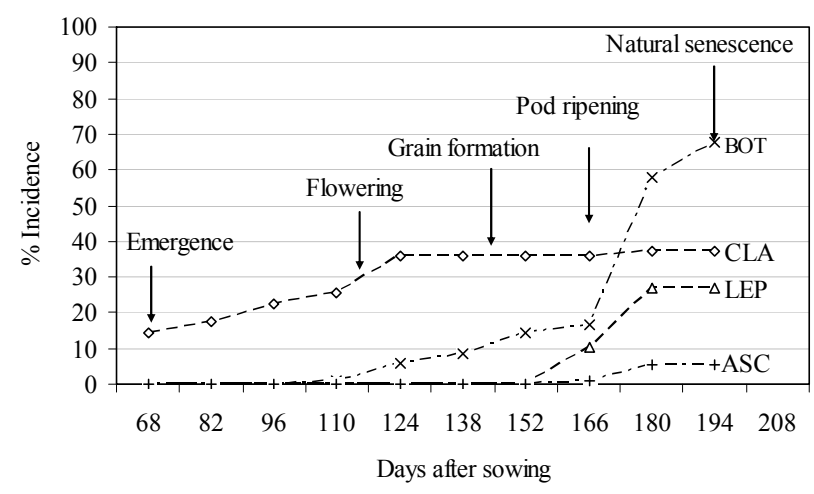

Figure 3. Incidence of leaf spot caused by different pathogens: BOT $=$ Botrytis sp., CLA = Cladosporium sp., LEP = Leptosphaerulina sp., ASC = Ascochyta sp.

sites during the vegetative growth of the plants. Problems appeared as isolated spots. Two species of Alternaria were present, A. tenuis and another that remains unidentified. The symptoms caused by Alternaria sp. were dark brown to blackish spots with irregular rings. Isolates grown on PDA and FBDA were violet-green and effuse. The conidiophores were mononematosus and solitary. The conidia were typically ovoclavate, brown in colour, with transversal and longitudinal septa, and with the beak greatly exceeding the length of the body. This agrees with the description of Alternaria sp. made by Ellis (1971) but differs to that for A. tenuis in terms of the conidiophores, the conidia, and the appropriate culture medium (Figure 2(c)).

The symptoms caused by Cercospora were similar. The spots were dark brown (more intense on the leaves) 
with irregular and tenuous rings. Isolated fungal structures were seen on both sides of the leaf. The conidiophores were in fascicles, stromatic, geniculated, and olive brown in colour. The hyaline conidia were septate and solitary. The characteristics of these structures were different to those of $C$. zonata as described by Chupp (1953), but resembled those of Cercospora sp. (Figure 2(d)).

\subsection{Incidence and Severity of Faba Bean Leaf Spot}

The treatments had no effect on the progress curve (DPC) for leaf spot incidence as a whole. One hundred percent incidence was reached on approximately day 90 (Figure 4(a)). The values for $\mathrm{R}^{2}$ and the mean square error (MSE) for $\mathrm{T}_{1}$ (Control) for the different models were: exponenttial $\mathrm{R}^{2}=0.99, \mathrm{MSE}=0.00397$; Gompertz $\mathrm{R}^{2}=0.74$, $\mathrm{MSE}=0.64$; logistic $\mathrm{R}^{2}=0.84$, $\mathrm{MSE}=0.63$; monomolecular $\mathrm{R}^{2}=0.6, \mathrm{MSE}=0.60$. The exponential model for $\mathrm{T}_{1}$ showed the highest $\mathrm{R}^{2}$ value (0.99) (Figure 5(a)).

However, the DPCs for each pathogen provided evidence of different growth patterns (Figure 3). The curves for Cladosporium and Botrytis sp. showed their incidence to be greater than those of Lepthoshaerulina and Ascochyta (Figure 3). Cladosporium sp. was detected from emergence until flowering, but after this phase incidence remained stable until ripening (Figure 3). With a fall in the incidence of Cladosporium sp., other types of leaf spot appeared. For example, chocolate leaf spot was present from flowering, gradually becoming the main disease present (Figure 3). The incidence of the remaining pathogens (Lepthoshaerulina and Ascochyta) was lower and they were only seen at ripening (Figure 3).

Significant differences were seen between the DPCs for severity $\left(\mathrm{F}_{0.05}\right)$ for leaf spot as a whole according to the treatment applied (Figure 4(b)). By the beginning of natural senescence (98 days), 40\% severity was reached by day 98 (the start of natural senescence). Treatments $T_{2}$ and $\mathrm{T}_{3}$ differed significantly from $\left(\mathrm{T}_{1}\right)\left(\mathrm{F}_{0.05}\right)$. The $\mathrm{R}^{2}$ and MSE values for severity in the $T_{1}$ treatment with each model were: exponential $\mathrm{R}^{2}=0.95$, $\mathrm{MSE}=0.13$; Gompertz $\mathrm{R}^{2}=0.99, \mathrm{MSE}=0.0034$; logistic $\mathrm{R}^{2}=0.97, \mathrm{MSE}$ $=0.09$; monomolecular $\mathrm{R}^{2}=0.86$, $\mathrm{MSE}=0.0049$. The Gompertzian model provided the highest $\mathrm{R}^{2}$ value $(0.99)$ (Figure 5(b)). Comparison of the linearised DPCs for severity for $T_{1}$ and $T_{3}$ shows (Figure 6) show no significant difference in apparent infection rates $(r)(r=0.0474$ for $\mathrm{T}_{1}$ and $\mathrm{r}=0.0577$ for $\mathrm{T}_{3}$ ).

\subsection{Grain Yield of Faba Beans}

Significant and even very significant differences were seen between treatments in terms of grain yield. Very significant differences $\left(\mathrm{F}_{0.01}\right)$ was seen between $\mathrm{T}_{3}(6.86$ $\left.\mathrm{Mg} \cdot \mathrm{ha}^{-1}\right)$ and $\mathrm{T}_{2}\left(6.52 \mathrm{Mg} \cdot \mathrm{ha}^{-1}\right)$ and the $\mathrm{T}_{1}$ control (4.39 $\mathrm{Mg} \cdot \mathrm{ha}^{-1}$ ) (Figure 7), and significant differences were seen between $\mathrm{T}_{4}$ (Trichoderma sp.) and $\mathrm{T}_{5}$. The plants treated with $\mathrm{T}_{2}, \mathrm{~T}_{3}, \mathrm{~T}_{4}$ and $\mathrm{T}_{5}$ produced 33, 36, 24 and $23 \%$ higher yields than the $\mathrm{T}_{1}$ (control) plants. The linear regression line for yield and disease severity had a negative slope ( -0.2176$)$; the $\mathrm{R}^{2}$ value was 0.99 (Figure 8).

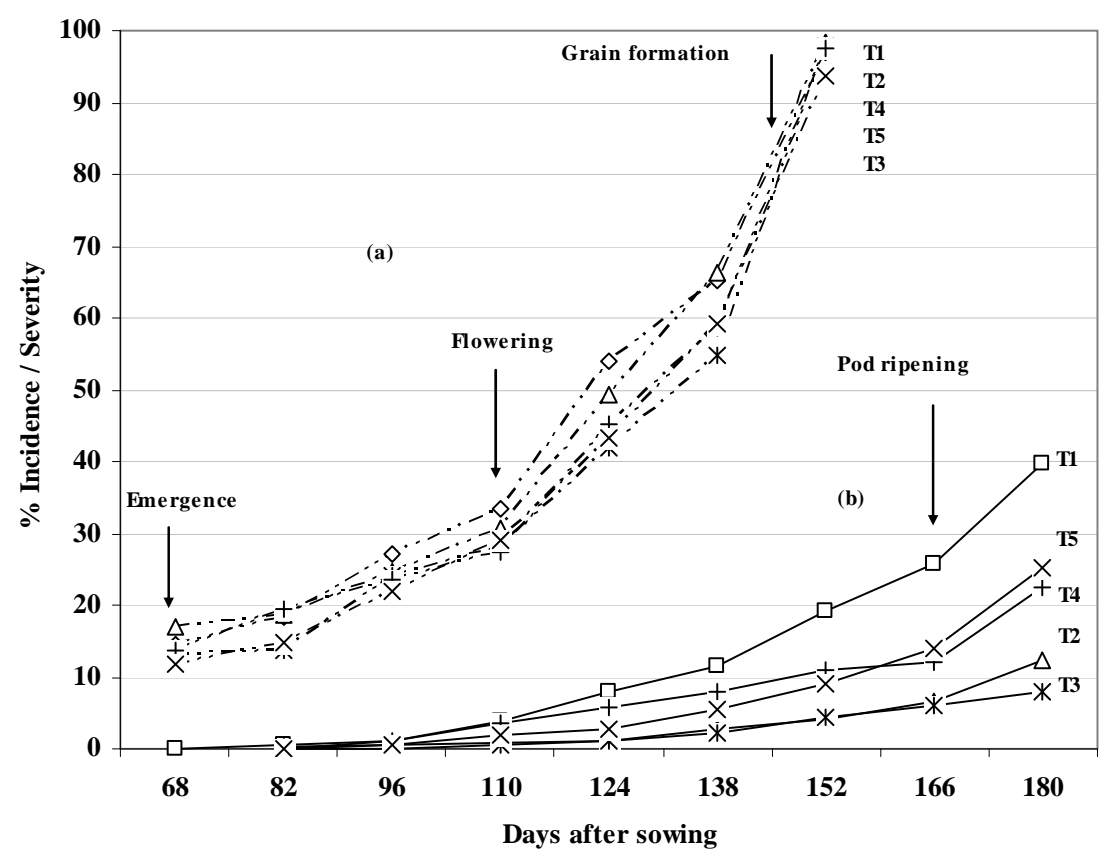

Figure 4. Leaf spot disease progress curves (highlighting different phenological stages) for the five treatments: (a) Incidence (---); (b) Severity (-). $T_{1}, T_{2}, T_{3}, T_{4}$ and $T_{5}$ are defined in Table 1. 


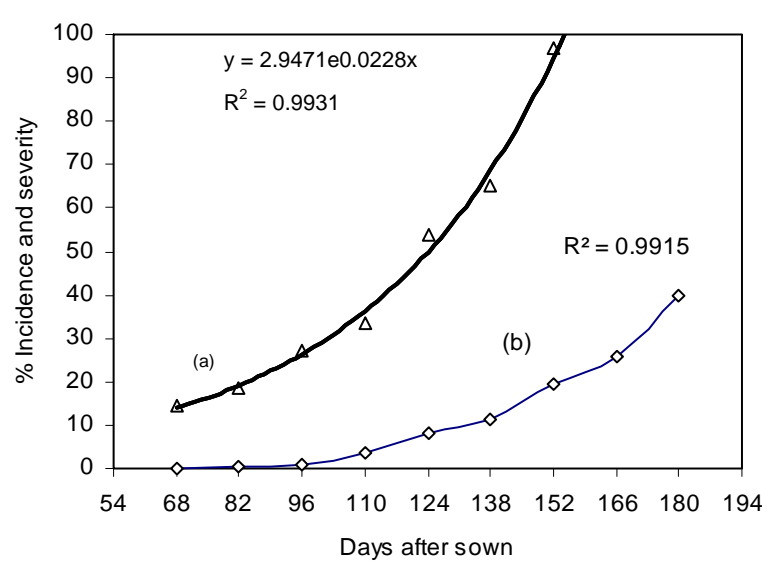

Figure 5. Change in leaf spot incidence (a) and severity (b) in $T_{1}$ (control treatment).

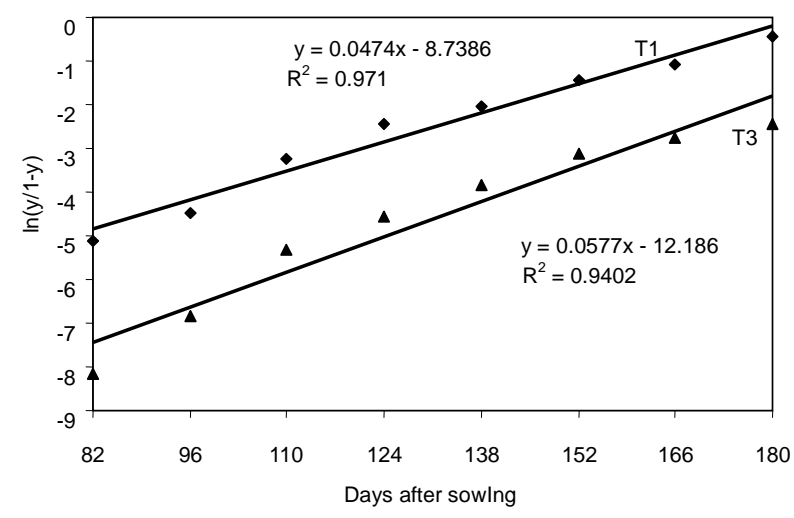

Figure 6. Severity (logit-transformed) over time for $T_{1}$ and $T_{3}$. These treatments are defined in Table 1 .

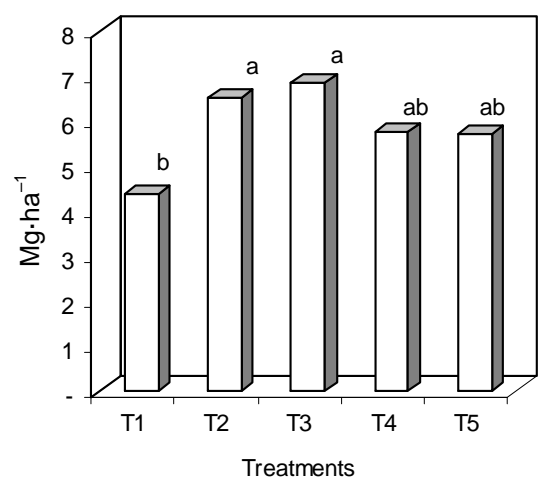

Figure 7. Dry grain yield (letters a and $b$ indicate significant differences at $F_{0.01}$ ) in $T_{1}, T_{2}, T_{3}, T_{4}$ and $T_{5}$ (treatments defined in Table 1).

\section{Discussion}

\subsection{New and Emerging Diseases}

The present work shows that the leaf spot disease affecting faba beans in the study region is a complex of fungal diseases caused by hemibiotrophic and necrotrophic pathogens $[10,22]$. According to the criteria of Damsteegt [6],

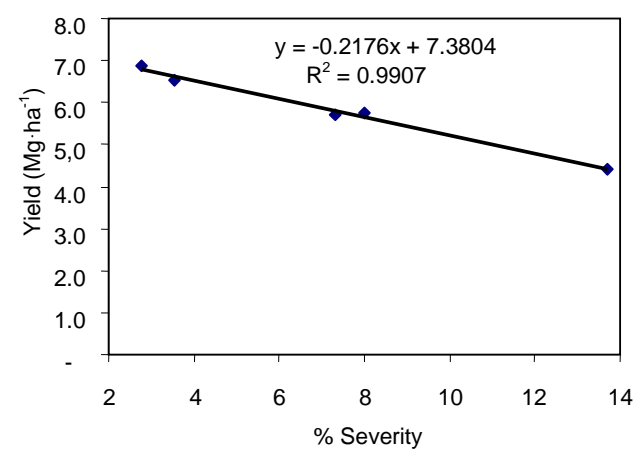

Figure 8. Linear regression line for yield $\left(\mathrm{Mg} \cdot \mathrm{ha}^{-1}\right)$ with respect to severity (\%).

these diseases were categorized as new (Cladosporium sp. and Lepthosphaerulina sp.) or emergent (Chocolate leaf spot, Ascochyta blight and Alternaria and Cercospora leaf spots). The new diseases are reported for the first time on faba bean in Bolivia. But, these were not of great importance. Among the emerging diseases, however, chocolate leaf spot was important; Ascochyta blight, Alternaria and Cercospora leaf spot were of less importance. Changes in the climate may be one of the reasons encouraging the appearance of new and emerging diseases. Garrett et al. [23] indicates that rising temperatures are bringing about the geographic expansion of pathogens, allowing them to come into contact with more potential hosts. This author also suggests that the temperature governs the rate of reproduction of many pathogens. For example, the germination of the uredospores of Puccinia substriata increases with temperature. Temperature may also influence the sexual or asexual reproduction of pathogen populations [23]. In Bolivia, changes in crop behaviour patterns have been noticed in recent years as well as in the incidence of disease and pests, all of which might be related to climate (mostly temperature) change. However, no studies have been performed that can confirm such climate change has occurred [24].

This study appears to confirm that the Alternaria spp. and Cercospora spp. detected are not those already known to cause leaf spot in faba bean (A. tenuis and $C$. zonata). The present work shows chocolate leaf spot to be caused by B. cinerea and B. fabae. Otazu et al. [3] and Piérola [25] also indicate that, in Bolivia, both spe- cies cause chocolate leaf spot. Hashim et al. [18] report the same for other countries. However, the importance of each species during the development of the disease as a whole was not evaluated. Under the conditions in a study by Hashim et al. [26], B. cinerea was found to mainly affect flowering, while $B$. fabae was present throughout the entire growth cycle.

The present work confirms $A$. fabae to be a causal agent of Ascochyta blight in Bolivia. Reports from other countries agree with this, and indicate that the disease 
appears on the leaves, stems, pods and grains [22,27]. Given the environmental conditions of the Altiplano, the disease does not develop very quickly and is seen only on the pods and stem during the ripening stage; it is therefore something of a minor problem for this crop.

Alternaria tenuis has been reported from other faba bean-producing areas of Bolivia [4]. However, the unidentified species of Alternaria detected is quite different to this species. Rahman et al. [28] have reported a third species of Alternaria-A. tenuissima-from Japan, where it affects faba bean. However, this is also a very different species to that detected in the present work.

\subsection{Leaf Spots Disease Intensity}

The DPCs for both disease incidence and severity show the different pathogens to be of different importance, and that the different treatments applied vary in their influence on these variables. The DPCs for incidence show the treatments to have no effect; all the curves reflect the exponential growth of the pathogens over 90 days. The appearance of epidemics depends on key variables, such as the size of the inoculum, its dispersion, the latent period of the pathogen, its infection period, the susceptibility of the host, and environmental conditions (including temperature and relative humidity) [29]. However, when the DPCs for incidence for each pathogen are examined separately, they are seen to be different. The DPC for Cladosporium shows this fungus to be present from emergence, although it never attains an incidence of $40 \%$ and is not of great importance. During the remainder of the growth cycle it generally behaves as a weak pathogen. The curve for chocolate leaf spot shows it to be present from flowering. Within 30 days its incidence can increase by $20 \%-70 \%$. During this time the pathogen seems to increase its rate of reproduction, becoming polycyclic, making it much more dangerous. De Quiton (2000) indicates chocolate leaf spot to be the most important leaf spot disease in areas $>3500 \mathrm{~m}$ in Bolivia. Other authors $[26,27]$ describe chocolate leaf spot as the most important disease to affect faba bean. The remaining diseases-Lepthosphaerulina and Ascochyta blightappear at low levels during ripening, probably depending on environmental conditions. Temperature and relative humidity are both key factors in the epidemiology of Ascochyta blight [22], which can be considered a minor disease in Bolivia.

The DPCs for severity show the different treatments to differ significantly in terms of disease control. The DPC for $T_{1}$ represents the natural conditions of infection, and is best described by a Gompertzian $\left(\mathrm{R}^{2}=0.99\right)$ or logistic $\left(\mathrm{R}^{2}=0.97\right)$ model. Both provide a range of curves that are similar [29]. However, like the DPCs for incidence, severity increases over a period of 90 days to attain a value of $40 \%$ that of $\mathrm{T}_{1}$ in the phase of crop ripening.
This shows that the rate of reproduction of the pathogens is probably low, and therefore their importance reduced. This is supported by the low infection rates obtained in $T_{3}(r=0.0577)$ compared to $T_{1}(r=0.0474)$ (Figure 6).

\subsection{Yield and Losses}

The impact and losses caused by leaf spot disease depends on the latter's progress. To reduce their impact the growth of the pathogens needs to be kept under control [21]. The disinfection of the seed plus leaf spray treatments $\left(T_{2}\right.$ and $\left.T_{3}\right)$ appeared to be more effective than $T_{4}$ or $\mathrm{T}_{5}$ (Figure 4(b)). This shows that seed treatment has an additional effect on the control of leaf spot, and that different fungicides have different effects.

Treatments $T_{2}$ and $T_{3}$, which involved alternate leaf treatment with benomyl-mancozeb, had a greater effect on the DPC for severity than did $\mathrm{T}_{4}$ (spraying with Trichoderma) or $\left(\mathrm{T}_{5}\right)$ (cymoxanil-mancozeb and chlorothalonil). This agree with the results of McLeod and Galloway (1996), who indicate that carbendazin efficiently controls chocolate leaf spot and that mancozeb efficiently controls Ascochyta blight and faba bean rust. Like benomyl, carbendazin, belongs to the benzimidazoles [30]. Foliar spraying with Trichoderma spp. $\left(\mathrm{T}_{4}\right)$ yield are reducing $24 \%$, compared with $\mathrm{T}_{3}(36 \%)$. According to Elmer and Reglinski [8], the effectiveness of Trichoderma spp. control was $36 \%$ compared to the $52 \%$ for standard botricides when applied to vines (Vitis vinifera) at four stages of growth in a vineyard. Similarly, Perelló et al. [9] reported Trichoderma spp. to significantly reduce leaf spot in wheat caused by Pyrenophora tritici-repentis $($ anamorph $=$ Drechslera tritici-repentis), both in vitro and under greenhouse conditions. Elad [7] indicates several modes of action to be involved in biocontrol.

The effects of the treatments on the DPCs for severity are reflected in the dry grain yield. $\mathrm{T}_{2}$ and $\mathrm{T}_{3}$ were associated with significantly higher yields than those seen in $\mathrm{T}_{1}, \mathrm{~T}_{4}$ or $\mathrm{T}_{5}$ (Figure 6). The dry grain yields for Usnayo did not agree with those reported by Heredia (1996) (3.6 - $4.1 \mathrm{Mg} \cdot \mathrm{ha}^{-1}$ for Bolivia), although they were close. The difference might be explained by differences in the cultivation of the crop, e.g., in shading (distance between rows) and banking-up practices. In this work, up to $36 \%$ losses in dry grain were caused by leaf spot disease. Heredia [2] and De Quitón [4] reported 20\% - 80\% losses due to chocolate leaf spot.

In conclusion, several pathogens cause leaf spot in faba bean in Bolivia. Some of the causal pathogens detected in this work were new while others were emerging. The results of modelling showed the pathogens identified to be moderately destructive, with chocolate leaf spot the most important. Spraying with Trichoderma spp. appears to reduce the impact of these pathogens on faba bean. 
Further works is needed on their biological control.

\section{Acknowledgements}

The authors wish thank Heditt Foronda Montoya, director of the Oficina Regional Semillas-La Paz, for collaboration us access to laboratories for the taxonomic identification of the pathogens studied, the Quinoa Project of the IRD, the French Office of Cooperation in Bolivia for providing us use of their Sigma Scan Pro software, thank Carmen de Blas (INIA-España) for comments and suggestions to the manuscript too, the Centro de Investigaciones y de Servicios en Teledetección, dependent of the Facultad de Ciencias Agrícolas, Pecuarias, Forestales y Veterinarias "Martín Cárdenas", Universidad Mayor de San Simón-Cochabamba, for the production of the map, and Francisco Mamani (a grower in Chirapaca) for his help in the field performance of this work.

\section{REFERENCES}

[1] F. Balderrama, V. Iriarte, O. Barea, G. Iporre and E. Carrasco, "Cadena Agroalimentaria del Haba de Altura para Exportación (Estudio Preliminar)," Fundación Proinpa, Cochabamba, 2001.

[2] G. Heredia, "Ensayos Regionales de Rendimiento de Haba de Altura," In: Informe Anual 1995-1996, Programa Nacional de Leguminosas de grano, Altiplano Norte, Instituto Boliviano de Tecnología Agropecuaria, La Paz, Bolivia, 1996, pp. 11-17.

[3] V. Otazu, W. M. Brown and M. de Quiton, "Enfermedades de las plantas en Bolivia," Ministerio de Asuntos Campesinos y Agropecuarios/Instituto Boliviano de Tecnología Agropecuaria/Consorcio Internacional para el Desarrollo, Cochabamba, 1982.

[4] M. De Quitón, "Enfermedades de Haba," In: H. Waaijenberg and M. Caro, Eds., Programa Nacional de Leguminosas de Grano: Resultados de Investigaciones, 19911998, Cochabamba, 2000, pp. 59-88.

[5] M. Coca-Morante, "Programa Tubérculos y Cultivos Andinos," Informe técnico Estación Experimental Belén, Facultad de Agronomía, Universidad Mayor de San Andrés, La Paz, 2002.

[6] V. D. Damsteegt, "New and Emerging Plant Viruses," 1999. http://www.apsnet.org/feature/newviruses/top.html

[7] Y. Elad, "Biological Control of Foliar Pathogens by Means of Trichoderma Harzianum and Potential Modes of Action," Crop Protection, Vol. 19, No. 8, 2000, pp. 709-714. doi:10.1016/S0261-2194(00)00094-6

[8] P. A. G. Elmer and T. Reglinski, "Review: Biosupression of Botrytis Cinerea in Grapes," Plant Pathology, Vol. 55, No. 2, 2006, pp. 155-177. doi:10.1111/j.1365-3059.2006.01348.x

[9] A. Perelló, C. Mónaco, M. R. Simón, M. Sisterna and G. Dal Bello, "Biocontrol Efficacy of Trichoderma Isolates for Tan Spot of Wheat in Argentina," Crop Protection,
Vol. 22, No. 9, 2003, pp. 1099-1106. doi:10.1016/S0261-2194(03)00143-1

[10] B. Williamson, B. Tudzynski, P. Tudzynski and J. A. Van Kan, "Botrytis Cinerea: The Cause of Grey Mould Disease," Molecular Plant Pathology, Vol. 8, No. 5, 2007, pp. 561-580. doi:10.1111/j.1364-3703.2007.00417.x

[11] D. Shtienberg, "Modelling: The Basis for Rational Disease Management," Crop Protection, Vol. 19, No. 8-10, 2000, pp. 747-752. doi:10.1016/S0261-2194(00)00099-5

[12] M. J. Jeger, "Analysis of Disease Progress as a Basis for Evaluating Disease Management Practices," Annual Review of Phytopathology, Vol. 42, 2004, pp. 61-82. doi:10.1146/annurev.phyto.42.040803.140427

[13] "Servicio Nacional de Hidrología y Meteorología," Resumen Climatológico del Altiplano de La Paz, 2005.

[14] C. Chúpp, "A Monograph of the Fungus Genus Cercospora," New York, 1953.

[15] C. Booth and K. A. Pirozynski, "CMI Description of Pathogenic Gungi and Bacteria, No. 146," Lepthosphaerulina trifolii, Commonwealth Mycological Institute, Ferry Lane, Kew, Surrey, 1967.

[16] M. B. Ellis, "Dematiaceous Hyphomycetes," Commonwealth Mycological Institute, Surrey, 1971.

[17] B. C. Sutton, "The Coelomycetes: Fungi Imperfect with Pycnidia Acervuli and Stromata," Commonwealth Mycological Institute, Surrey, 1980.

[18] R. T. Hanlin, "Illustrated Genera of Ascomycetes," APS Press, Minnesota, 1990.

[19] M. Coca-Morante, "Hongos Parásitos y Saprofíticos Foliares en pino de cerro (Podocarpus parlatorei)," Facultad de Agronomía, Universidad Mayor de San Andrés, La Paz, 2004.

[20] C. L. Campbell and L. V. Madden, "Introduction to Plant Disease Epidemiology,” Wiley, New York, 1990.

[21] P. A. Arneson, "Plant Diseases Epidemiology: Temporal Aspects," The American Phytopathological Society, Minnesota, 2001.

[22] B. Tivoli and S. Banniza, "Comparison of the Epidemiology of Ascochyta Blights on Grain Legumes," European Journal of Plant Pathology, Vol. 119, No. 1, 2007, pp. 59-76. doi:10.1007/s10658-007-9117-9

[23] K. A. Garrett, S. P. Dendy, E. E. Frank, M. N. Rouse and S. E. Travers, "Climate Change Effects on Plant Disease: Genomes to Ecosystems," Annual Review of Phytopathology, Vol. 44, 2006, pp. 489-509. doi:10.1146/annurev.phyto.44.070505.143420

[24] Programa Nacional De Cambios Climáticos, "Vulnerabilidad y Adaptación al Cambio y Variabilidad Climática de los Sistemas Alimentarios en zonas Semiáridas de Montaña: Sistematización de una Experiencia de Consultas a Diferentes Niveles de Decisión," Ministerio de Desarrollo Sostenible y Planificación, Viceministerio de Medio Ambiente, Recursos Naturales y Desarrollo Forestal, PNCC/PNUD/MDSP, La Paz, 2002.

[25] L. A. Piérola, "Estrategias del cultivo de haba en Bolivia," En: Memorias III Reunión Nacional en Leguminosas y IV Reunión Boliviana de Rhizobiologia, UNIR/UMSA- 
Embajada de los Países Bajos-Prosuko-Embajada de Gran Bretaña-Abryl, La Paz, 1997.

[26] M. Hashim, J. A. Roberts, S. Rossall and M. J. Dickinson, "Leaflet Abscission and Phytoalexin Production during the Response of Two Faba Bean Breeding Lines to Botrytis Infection," Plant Pathology, Vol. 46, No. 6, 1997, pp. 989-996. doi:10.1046/j.1365-3059.1997.d01-85.x

[27] B. MacLeod and J. Galloway, "Faba Bean: Fungicide Control of Leaf Diseases," Department of Agriculture, Government of Western Australia, Farmnote, 2002.

[28] M. Z. Rahman, Y. Honda, S. Z. Islam, N. Muroguchi and
S. Arase, "Leaf Spot Disease of Broad Bean (vicia faba L.) Caused by Alternaria tenuissima-A New Disease in Japan," Journal of General Plant Pathology, Vol. 68, No. 1, 2002, pp. 31-37. doi:10.1007/PL00013049

[29] A. van Maanen and X.-M. Xu, "Modelling Plant Disease Epidemics," European Journal of Plant Pathology, Vol. 109, No. 7, 2003, pp. 669-682. doi:10.1023/A:1026018005613

[30] C. J. Delp, Ed, "Fungicide Resistance in North America," The American Phytopathological Society, Minnesota, 1988. 